Original Research

\title{
Analisis Kepuasan Pelanggan Batik Benang Bintik di Kota Palangka Raya
}

\author{
Wenny Indriastuti ${ }^{1,}{ }^{*}$, Meitiana $^{2}$, Bambang Mantikei ${ }^{2}$ \\ ${ }^{1}$ Badan Perencanaan Pembangunan Daerah, Penelitian dan Pengembangan Kota Palangka Raya \\ ${ }^{2}$ Pogram Studi Magister Manajemen Program Pascasarjana Universitas Palangka Raya \\ * Korespondensi: Wenny Indriastuti (Email: wenny indriastuti@yahoo.co.id)
}

\begin{abstract}
This research aims to determine the level of customer satisfaction of Batik Benang Bintik in Palangka Raya. This research is a quantitative research with field survey techniques. The subjects of the research are 75 customers of Batik Benang Bintik in Palangka Raya with different age and backgrounds. The data were collected through interview and questionnaire instrument which is consist of 15 questions that have previously tested for its validity and reliability. The costumers' satisfaction were analysed in term of costumer service, promotion, price and shop location in the city. We do hope this research may provide insight to business owner and local government in their effort to enhace the potential market of Batik Benang Bintik, especially in Palangka Raya city.
\end{abstract}

Keywords Batik Benang Bintik, customer satisfaction

\section{PENDAhUluAN}

Salah satu produk industri Indonesia yang banyak diminati masyarakat lokal maupun internasional adalah Batik (Kementerian Perindustrian Republik Indonesia, 2018; Nurainun, 2008). Batik sudah menjadi trend di kalangan masyarakat, baik tua maupun muda (Kustiyah, 2017; dan Purba dan Prasetyo, 2018). Ketenaran batik bahkan hingga ke manca negara. Pada tanggal 2 Oktober 2009 batik Indonesia diakui secara internasional melalui organisasi pendidikan dan kebudayaan dunia yang berada di bawah naungan Perserikatan Bangsa Bangsa (PBB), yaitu UNESCO (Wibowo et al., 2017; Kurniasih, 2018; dan Widiasti, 2017). Di Kalimantan Tengah, kesenian kain batik dinamakan sebagai Benang Bintik. Motif yang dituangkan pada kain biasanya menggambarkan budaya masyarakat setempat yang mayoritas dihuni oleh suku Dayak. Beberapa motif khas kebudayaan suku Dayak antara lain seperti alat tradisional, rumah adat, pohon Batang Garing dan lukisanlukisan khas suku Dayak Ngaju (Kalteng.net, 2014; Alexandro et al., 2020).

Dalam penggunaan Batik Benang Bintik sendiri di keseharian, Pemerintah Kota Palangka Raya juga memiliki peran yang cukup andil dalam mempromosikan Batik Benang Bintik. Beberapa upaya Pemerintah Kota Palangka
Raya tersebut adalah dengan menjadikan Benang Bintik sebagai pakaian wajib Aparatul Sipil Negara (ASN) setiap hari Kamis dan Jumat, sebagai pakaian adat atau pegelaran seni, dijadikan tema wajib dalam lomba fashion, sebagai souvenir bagi tamu yang berkunjung dan oleh-oleh khas Kalimantan Tengah. Banyak gerai-gerai Benang Bintik bermunculan, antusias masyarakat lokal terhadap Benang Bintik juga positif, desain-desain baru juga mulai dimunculkan sesuai minat dari pasar. Sehingga minat pembeli batik benang bintik pun mulai meningkat. Melihat tingginya permintaan pasar dari batik benang bintik harus sesuai dengan daya beli masyarakat yang disesuaikan kondisi harga pasar dan lokasi yang strategis.

Kegiatan pembelian adalah salah satu tahap dari keseluruhan proses keputusan pembelian konsumen. Proses keputusan pembelian konsumen meliputi tahap pengenalan kebutuhan, pencarian informasi, evaluasi alternatif, pembelian, dan evaluasi proses pembelian. Dalam menentukan pilihannya, konsumen tentunya mempunyai pertimbangan tertentu dan terdapat hal-hal yang paling berpengaruh diantaranya adalah faktor-faktor seperti produk yang disajikan, harga, kualitas pelayanan, promosi dan lokasi yang dilakukan tempat usaha untuk dapat menarik minat konsumen (Kotler dan Amstrong, 2017). Dalam kegiatan bisnis salah satu cara untuk 
meningkatkan daya saing suatu perusahaan atau pebisnis adalah dengan menghadirkan produk yang mempunyai kualitas tinggi serta mampu memenuhi keinginan konsumen, harga yang terjangkau, serta promosi yang menarik.

Berdasarkan paparkan di atas, diperlukan suatu penelitian dengan tujuan menganalisis kepuasan pelanggan batik benang bintik di Kota Palangka Raya. Penelitian mengukur seberapa besar kepuasan pelanggan jika dilihat dari 4 (empat) aspek, yakni pelayanan, harga, lokasi, dan promosi. Dengan adanya pengukuran kepuasan pelanggan berdasarkan keempat aspek tersebut, diharapkan dapat menggambarkan secara garis besar tentang kondisi tingkat kepuasan pelanggan Batik Benang Bintik khususnya di Kota Palangka Raya.

\section{METODOLOGI}

Penelitian ini merupakan penelitian dengan metode kuantitatif. Menurut Unaradjan (2019), penelitian kuantitatif merupakan penelitian dimana dalam analisis data menggunakan perhitungan angka-angka yang diperoleh dengan menggunakan rumus-rumus tertentu. Metode penelitian yang digunakan adalah metode survei. Teknik pengambilan sampel yang digunakan adalah teknik sampling dengan pendekatan Non-probability Sampling, dimana suatu pengambilan sampel yang tidak memberi peluang atau kesempatan sama bagi setiap unsur atau anggota populasi untuk dipilih menjadi sampel (Sugiyono, 2017). Selain itu teknik pengumpulan data yang digunakan adalah dengan teknik wawancara dan kuisioner, sedangkan analisis data dilakukan dengan analisis tingkat kepuasan pelanggan. Terdapat 4 (empat) aspek kepuasan pelanggan yang menjadi fokus peneliti dalam penelitian ini yakni pelayanan, harga, lokasi, dan promosi. Dengan adanya keempat aspek tersebut, peneliti menuangkannya ke dalam 15 poin pertanyaan dalam kuisioner, dimana dalam kuisioner tersebut skala yang digunakan mengikuti skala likert. Uji validitas dan reliabilitas dilakukan terhadap kuisioner yang digunakan. Subjek penelitian adalah pelanggan Batik Benang Bintik yang ada di Kota Palangka Raya yang berjumlah 75 orang dengan latar belakang pekerjaan yang berbeda.

\section{HASIL}

\subsection{Karakteristik Pelanggan}

Pelanggan batik benang bintik dikaraterisasi menurut dua bagian, yakni berdasarkan jenis kelamin dan usia. Tabel 1 menggambarkan bahwa pelanggan dengan jenis kelamin laki-laki sebanyak 29 orang (38,7\%), sedangkan pelanggan perempuan berjumlah 46 orang (61,3\%). Pelanggan dengan usia di bawah 25 tahun sebanyak 15 orang (20\%), berusia antara 25 tahun hingga 40 tahun sebanyak 34 orang $(45,3 \%)$, dan berusia diatas 40 tahun sebanyak 26 orang $(34,7 \%)$.

Tabel 1. Karakterisitik pelanggan

\begin{tabular}{llcc}
\hline Karakteristik & \multicolumn{1}{c}{ Kategori } & Jumlah & Persentase \\
\hline \multirow{3}{*}{ Jenis Kelamin } & Laki-laki & 29 & $38,7 \%$ \\
& Perempuan & 46 & $61,3 \%$ \\
& Total & $\mathbf{7 5}$ & $\mathbf{1 0 0 , 0 \%}$ \\
\hline \multirow{2}{*}{ Usia } & $<25$ tahun & 15 & $20,0 \%$ \\
& $25-40$ tahun & 34 & $45,3 \%$ \\
& $>40$ tahun & 26 & $34,7 \%$ \\
& Total & $\mathbf{7 5}$ & $\mathbf{1 0 0 , 0 \%}$ \\
\hline
\end{tabular}

\subsection{Uji Validitas}

Uji validitas digunakan untuk mengukur sejauh mana alat ukur dapat mengukur sesuatu yang ingin diukur (Suwartono dan Moningka, 2017). Uji validitas digunakan untuk menguji tingkat kesahan suatu instrument pada masing-masing variablel dalam hal ini pada 15 poin pertanyaan yang diajukan di dalam kuisioner. Sebuah instrumen dikatakan valid apabila mampu mengukur apa yang diinginkan dan dapat mengungkapkan data dari variabel yang akan diteliti secara tepat. Hasil uji validitas instrumen penelitian disajikan pada Tabel 2.

Berdasarkan data-data yang dipaparkan pada Tabel 2 uji validitas, ditemukan bahwa instrumen yang digunakan dalam penelitian ini secara keseluruhan dinyatakan valid karena $R_{\text {Hitung }}>R_{\text {Tabel. }}$. Hasil penelitian ini sesuai dengan pendapat Arikunto (2006), bahwa instrumen penelitian dikatakan valid, apabila memiliki nilai pearson correlaion $\mathrm{R}_{\text {Hitung }}>\mathrm{R}_{\text {Tabel. }}$ Validitas instrumen yang digunakan terbukti dengan semua butir-butir pertanyaan yang diajukan dalam kuisioner memiliki nilai R-Hitung lebih besar dibandingkan R-Tabel. Dalam penelitian ini, Taraf Signifikansi yang digunakan dalam R-tabel adalah 5\% dan dengan jumlah responden (pelanggan) yang mengisi kuisioner berjumlah 75 orang.

\subsection{Uji Reabilitas}

Uji reliabilitas digunakan untuk mengukur derajat ketepatan atau keakuratan suatu instrumen penelitian (Suwartono dan Moningka, 2017). Sebuah instrumen dikatakan reliabel apabila instrumen tersebut mampu mengungkapkan data yang dapat dipercaya dan sesuai dengan kenyataan sebenarnya. Berdasarkan data pada Tabel 3 uji reliabilitas yang digunakan dalam penelitian ini merujuk pada konsep Cronbach's Alpha. Tabel 3 adalah hasil uji reliabilitas instrumen penelitian.

Tabel 3. Hasil uji reliabilitas instrumen penelitian

\begin{tabular}{cc}
\hline \multicolumn{2}{c}{ Reliabilitas instrumen } \\
\hline Cronbach's Alpha & $\begin{array}{c}\text { N Butir pertanyaan } \\
\text { (dalam kuisioner) }\end{array}$ \\
\hline $\mathbf{0 , 9 0 2 6 5 3}$ & 15 \\
\hline
\end{tabular}


Tabel 2. Validitas aspek kepuasan pelanggan

\begin{tabular}{|c|c|c|c|c|}
\hline No. & Pertanyaan & R-Hitung & $\begin{array}{l}\text { R-Tabel (Taraf } \\
\text { Signifikan } 5 \% \text { ) }\end{array}$ & Keterangan \\
\hline & Aspek Pelayanan & & & \\
\hline 1 & $\begin{array}{l}\text { Citra IKM yang bersangkutan merupakan IKM dengan pelayanan } \\
\text { yang ramah dan terpercaya }\end{array}$ & 0,6413 & 0,1888 & Valid \\
\hline 2 & Karyawan IKM bersikap sopan dan ramah dalam melayani saya & 0,6364 & 0,1888 & Valid \\
\hline 3 & $\begin{array}{l}\text { IKM memberikan keamanan dan kepercayaan terhadap proses } \\
\text { transaksi yang dilakukan }\end{array}$ & 0,3885 & 0,1888 & Valid \\
\hline 4 & Karyawan IKM berpenampilan rapi dan menarik & 0,5292 & 0,1888 & Valid \\
\hline \multirow[t]{2}{*}{5} & $\begin{array}{l}\text { IKM dapat memenuhi kebutuhan pelanggan seputar produk- } \\
\text { produk yang dipasarkan }\end{array}$ & 0,5950 & 0,1888 & Valid \\
\hline & Aspek Promosi & & & \\
\hline 6 & $\begin{array}{l}\text { IKM menawarkan produk Benang Bintik dengan desain/gaya/style } \\
\text { yang mengikuti perkembangan zaman namun tanpa mengurangi } \\
\text { nilai yang terkandung dari batik Benang Bintik itu sendiri }\end{array}$ & 0,6166 & 0,1888 & Valid \\
\hline 7 & $\begin{array}{l}\text { IKM menawarkan berbagai macam produk Benang Bintik dengan } \\
\text { kualitas kain yang baik }\end{array}$ & 0,7120 & 0,1888 & Valid \\
\hline 8 & $\begin{array}{l}\text { IKM menawarkan berbagai macam produk Benang Bintik tidak } \\
\text { hanya kain motif benang bintik, baju Batik Benang Bintik, dan } \\
\text { celana Batik Benang Bintik }\end{array}$ & 0,5577 & 0,1888 & Valid \\
\hline 9 & $\begin{array}{l}\text { IKM menawarkan berbagai macam produk Benang Bintik dengan } \\
\text { pola batik yang bermacam-macam }\end{array}$ & 0,6003 & 0,1888 & Valid \\
\hline 10 & $\begin{array}{l}\text { IKM menawarkan berbagai macam produk Benang Bintik dengan } \\
\text { pola warna yang beraneka ragam }\end{array}$ & 0,6639 & 0,1888 & Valid \\
\hline 11 & $\begin{array}{l}\text { Informasi-informasi terbaru/terupdate tentang produk selalu } \\
\text { diinformasikan karyawan IKM kepada pelanggan setiap saat } \\
\text { melalui media sosial }\end{array}$ & 0,6574 & 0,1888 & Valid \\
\hline 12 & Proses penjualan produk dapat dilakukan secara online & 0,6835 & 0,1888 & Valid \\
\hline \multirow[t]{2}{*}{13} & $\begin{array}{l}\text { IKM memiliki system teknologi informasi yang modern dalam } \\
\text { memasarkan produk-produknya }\end{array}$ & 0,5870 & 0,1888 & Valid \\
\hline & Aspek Harga & & & \\
\hline \multirow[t]{2}{*}{14} & $\begin{array}{l}\text { IKM menjual produk dengan harga-harga yang terjangkau oleh } \\
\text { masyarakat/pembeli }\end{array}$ & 0,4859 & 0,1888 & Valid \\
\hline & Aspek Lokasi & & & \\
\hline 15 & Lokasi IKM strategis & 0,6340 & 0,1888 & Valid \\
\hline
\end{tabular}

Berdasarkan Tabel 3, nilai cronbach alpha $>0,60$ yaitu sebesar 0,902653, dengan demikian instrumen penelitian tersebut dikatakan reliabel. Yusup (2018) menyatakan bahwa instrumen penelitian dapat dikatakan reliabel apabila nilai Cronbach Alpha > 0,60 dengan mengacu kepada ketetapan nilai reliabilitas.

\subsection{Tingkat Kepuasan Pelanggan}

Kepuasan pelanggan batik benang bintik diukur dengan skala likert yang menggunakan metode scoring 1 sampai 5 dengan kriteria sebagai berikut:

- Skor 5 = Sangat Puas

- Skor 4 = Puas

- Skor 3 = Cukup Puas
- Skor 2 = Tidak Puas

- Skor 1 = Sangat Tidak Puas

Tingkat kepuasan pelanggan pada berbagai aspek disajikan pada Tabel 4. Berdasarkan Tabel 4 diketahui bahwa $86,9 \%$ pelanggan merasa sangat puas terhadap pelayanan yang diberikan oleh pelaku usaha atau IKM Batik Benang Bintik di Kota Palangka Raya. Sebanyak 13,1\% pelanggan merasa puas terhadap aspek pelayanan yang diberikan oleh pelaku pelaku usaha. Tentu jika dilihat dari angka tersebut, bisa dikatakan bahwa sebagian besar pelanggan Batik Benang Bintik merasa puas dengan pelayanan yang diberikan baik oleh pelaku usaha maupun IKM yang menjual Batik Benang Bintik. 
Tabel 4. Tingkat kepuasan pelanggan pada bebagai aspek

\begin{tabular}{lccccc}
\hline Kategori kepuasan & $\begin{array}{c}\text { Aspek } \\
\text { pelayanan }\end{array}$ & Aspek promosi & Aspek harga & Aspek lokasi & $\begin{array}{c}\text { Aspek } \\
\text { keseluruhan }\end{array}$ \\
\hline Sangat Puas & $86,9 \%$ & $82,5 \%$ & $73,4 \%$ & $74,7 \%$ & $82,8 \%$ \\
Puas & $13,1 \%$ & $14,7 \%$ & $26,6 \%$ & $20,0 \%$ & $15,3 \%$ \\
Cukup Puas & $0,0 \%$ & $2,8 \%$ & $0,0 \%$ & $5,3 \%$ & $1,9 \%$ \\
Tidak Puas & $0,0 \%$ & $0,0 \%$ & $0,0 \%$ & $0,0 \%$ & $0,0 \%$ \\
Sangat Tidak Puas & $0,0 \%$ & $0,0 \%$ & $0,0 \%$ & $0,0 \%$ & $0,0 \%$ \\
\hline
\end{tabular}

Tabel 4 menggambarkan bahwa sebesar 82,5\% pelanggan merasa sangat puas terhadap promosi yang diberikan oleh pelaku usaha atau IKM Batik Benang Bintik dan sebanyak $14,7 \%$ pelanggan merasa puas terhadap aspek promosi yang diberikan oleh pelaku pelaku usaha atau IKM. Sedangkan sebesar 2,8\% pelanggan merasa cukup puas terhadap aspek promosi yang diberikan oleh pelaku pelaku usaha atau IKM. Apabila melihat data tersebut, sebagian besar pelanggan puas terhadap promosi yang diberikan baik oleh pelaku usaha maupun IKM yang menjual Batik benang Bintik. Namun masih terdapat pelanggan yang merasa belum puas terhadap promosi yang diberikan. Ketika ditelusuri lebih mendalam, peneliti menemukan bahwa ketidakpuasan sebagian pelanggan dikarenakan terdapat pelanggan yang masih belum mahir bahkan belum bisa mengeporasikan alat-alat telekomunikasi seperti handphone maupun laptop. Sehingga mereka ketinggalan informasi tentang produkproduk apa saja yang dipromosikan khususnya secara online.

Tabel 4 juga menggambarkan bahwa $73,4 \%$ pelanggan merasa sangat puas terhadap harga yang diberikan, dan $26,6 \%$ pelanggan merasa puas terhadap harga yang diberikan oleh pelaku pelaku usaha atau IKM. Sebanyak $74,7 \%$ pelanggan merasa puas terhadap lokasi atau tempat jual beli Batik Benang Bintik di Kota Palangka Raya, dan $20 \%$ pelanggan merasa puas terhadap aspek lokasi. Sebanýak 5,3\% pelanggan merasa cukup puas terhadap aspek lokasi dari pelaku usaha atau IKM.

Secara keseluruhan diketahui bahwa mayoritas (82,8\%) pelanggan merasa sangat puas terhadap Batik Benang Bintik di Kota Palangka Raya. Sisanya, sebanyak 15,3\% pelanggan merasa puas, dan $1,9 \%$ pelanggan merasa cukup puas.

\section{PEMBAHASAN}

\subsection{Tingkat Kepuasan pelanggan pada Aspek Pelayanan}

Berdasarkan data yang dikemukakan diketahui bahwa sebanyak $86,9 \%$ pelanggan merasa sangat puas terhadap pelayanan yang diberikan oleh pelaku usaha atau IKM Batik Benang Bintik di Kota Palangka Raya. Sedangkan 13,1\% pelanggan merasa biasa-biasa saja atau berskap netral terhadap aspek pelayanan yang diberikan oleh pelaku pelaku usaha atau IKM. Angka tersebut mengindikasikan bahwa sebagian besar pelanggan Batik Benang Bintik merasa puas dengan pelayanan yang diberikan baik oleh pelaku usaha maupun IKM yang menjual Batik benang Bintik.

Aspek pelayanan yang dimiliki oleh karyawan akan mempengaruhi kepuasan pelanggan yang dilayaninya, karena apabila pelaku usaha atau IKM Batik Benang Bintik di Kota Palangka Raya tidak melayani pelanggannya dengan baik, maka pelanggan akan merasa kecewa terhadap pelaku usaha atau IKM Batik Benang Bintik di Kota Palangka Raya. Dan pelayanan yang baik akan mampu menyelesaikan setiap persoalan yang terjadi, baik itu yang bersangkutan dengan produk maupun persoalan antara pelaku usaha atau IKM Batik Benang Bintik di Kota Palangka Raya dengan pelanggan. Aspek pelayanan diuji pada setiap pelaksanaannya, jika personel jasa membosankan, tidak dapat menjawab pertanyaan sederhana, atau saling berkunjung ke personal lain sementara pelanggan menunggu, pelanggan akan berfikir dua kali untuk melakukan bisnis lagi dengan penjual itu.

Pada penelitian ini, tingkat kepuasan pelanggan pada aspek pelayanan yang memiliki frekuensi terbanyak berada pada kategori sangat puas yaitu sebanyak 86,9\% dari keseluruhan subjek penelitian. Hal ini menunjukkan bahwa pelanggan Batik Benang Bintik di Kota Palangka Raya sangat puas, baik pada pelayanan pelaku usaha atau IKM Batik Benang Bintik di Kota Palangka Raya maupun pada produk yang disediakan.

\subsection{Tingkat Kepuasan pelanggan pada Aspek Promosi}

Adriani \& Realize (2018) mengatakan Promosi adalah unsur dalam bauran pemasaran perusahaan yang didayagunakan untuk memberitahukan, membujuk, dan mengingatkan tentang produk perusahaan. Menurut (Kotler \& Armstrong, 2017), kepuasan pelanggan merupakan suatu pandangan pelangan terhadap produk baik itu perasaan puas dan kecewa terhadap produk tersebut.

Pada penelitian ini, hasil perhitungan presentase menggambarkan bahwa sebesar $82,5 \%$ pelanggan merasa sangat puas terhadap promosi yang diberikan oleh pelaku usaha atau IKM Batik Benang Bintik di Kota Palangka Raya. Selain itu sebesar $14,7 \%$ pelanggan merasa puas terhadap 
aspek promosi yang diberikan oleh pelaku pelaku usaha atau IKM. sedangkan sebesar 2,8\% pelanggan merasa cukup puas terhadap aspek promosi yang diberikan oleh pelaku pelaku usaha atau IKM. Data tersebut menggambarkan sebagian besar pelanggan puas terhadap promosi yang diberikan baik oleh pelaku usaha maupun IKM yang menjual Batik benang Bintik. Namun masih terdapat pelanggan yang merasa belum puas terhadap promosi yang diberikan.

Ketika ditelusuri lebih mendalam, peneliti menemukan bahwa ketidakpuasan sebagian pelanggan dikarenakan terdapat pelanggan yang masih belum mahir bahkan belum bisa mengeporasikan alat-alat telekomunikasi seperti handphone maupun laptop. Sehingga mereka ketinggalan informasi tentang produk-produk apa saja yang dipromosikan khususnya secara online. Hal-hal yang perlu untuk diperbaiki untuk meningkatkan kepuasan pelanggan adalah dengan menambah frekuensi pemberian promosi dan memperbanyak mengadakan kegiatan sponsorship berupa pelatihan/seminar/workshop untuk pelaku usaha atau IKM Batik Benang Bintik di Kota Palangka Raya.

\subsection{Tingkat Kepuasan pelanggan pada Aspek Harga}

Pada penelitian ini, sebanyak $73,4 \%$ pelanggan merasa sangat puas terhadap harga yang diberikan oleh pelaku usaha atau IKM Batik Benang Bintik di Kota Palangka Raya. Sedangkan 26,6\% pelanggan merasa puas terhadap harga yang diberikan oleh pelaku pelaku usaha atau IKM.

Harga sendiri merupakan hal yang sangat krusial dalam bisnis. Harga benar-benar harus dipertimbangkan dengan serius karena menyangkut keterjangkauan konsumen pada produk dan sebaliknya juga menentukan tingkat keuntungan yang bisa diraih (Wahyuni dan Kurniawan, 2019). Harga pun menjadi salah satu faktor kepuasan pelanggan dimana kecendrungan konsumen memilih layanan yang dengan manfaat yang serupa ialah berasan keterjangkauannya, dalam hal ini value of money yang akan di dapatkan oleh konsumen. Harga sebagai faktor kepuasan pelanggan juga tidak terlepas dari apa yang didapatkan dari jumlah uang yang dikeluarkan. Terdapat empat indikator yang mencirikan harga, yaitu keterjangkauan harga, daya saing harga, kesesuaian harga dengan produk yang didapatkan, dan kesesuaian produkdengan manfaat yang didapatkan. Hal ini dapat menyimpulkan kepuasan pelanggan terhadap harga yang diberikan (Stanton, 1998).

Harga dilihat dari sudut pandang pelanggan, seringkali digunakan sebagai indikator nilai bilamana harga tersebut dihubungkan dengan manfaat yang dirasakan atas suatu barang atau jasa. Pada tingkat haga tertentu, jika manfaat yang dirasakan meningkat, maka nilainya akan meningkat pula. Apabila nilai yang dirasakan pelanggan semakin tinggi, maka akan menciptakan kepuasan pelanggan yang maksimal (Tjiptono, 1999). Indikator penilaian harga dapat dilihat dari kesesuaian antara suatu pengorbanan dari pelanggan terhadap nilai yang diterimanya setelah melakukan pembelian, dan dari situlah pelanggan akan mempersepsi dari produk atau jasa tersebut (Kertajaya, 2002). Persepsi yang positif merupakan hasil dari rasa puas akan suatu pembelian yang dilakukannya, sedangkan persepsi yang negatif merupakan suatu bentuk dari ketidakpuasan pelanggan atas produk atau jasa yang dibelinya.

\subsection{Tingkat Kepuasan pelanggan pada Aspek Lokasi}

Pada penelitian ini diketahui bahwa sebanyak $74,7 \%$ pelanggan merasa puas terhadap lokasi atau tempat jual beli Batik Benang Bintik di Kota Palangka Raya. Sebanyak $20 \%$ pelanggan merasa puas dan 5,3\% pelanggan merasa cukup puas terhadap aspek lokasi dari pelaku usaha atau IKM.

Pada umumnya gerai atau toko yang berada pada lokasi yang tepat atau strategis akan lebih sukses dibandingkan gerai lainnya yang berlokasi kurang strategis. Menurut Kotler dan Amstrong (2017), salah satu kunci menuju sukses usaha adalah lokasi karena lokasi menentuka komunitas yang akan ditarget oleh pengusaha. Keputusan ini sangat bergantung pada potensi pertumbuhan ekonomis dan stabilitas, persaingan, iklim politik, dan sebagainya. Semakin strategis lokasi yang dipilih maka semakin bagus pula prospek untuk mendapatkan pelanggan baru. Data yang diperoleh dari penelitian ini menyatakan bahwa lokasi merupakan faktor yang tidak kalah penting untuk di pertimbangkan.

\subsection{Tingkat Kepuasan pelanggan Secara Keseluruhan}

Hasil penelitian menunjukkan bahwa sebesar $82,8 \%$ pelanggan merasa sangat puas terhadap Batik Benang Bintik di Kota Palangka Raya, sementara 15,3\% pelanggan merasa puas, dan sebanyak $1,9 \%$ pelanggan merasa cukup puas.

Adanya kesesuaian antara pelayanan, promosi, harga dan lokasi dapat membuat kepuasan bagi pelanggan. Dengan meningkatkan mutu yang lebih baik diharapkan pelanggan akan merasa puas dan dengan begitu pelanggan tidak meninggalkan produk/jasa Batik Benang Bintik dikemudian hari, sehingga akan menguntungkan pelaku usaha atau IKM Batik Benang Bintik di Kota Palangka Raya. Menurut Parasuraman et al. (2005), terdapat 3 faktor yang dapat dikendalikan oleh pasar yang mempengaruhi kepuasan pelanggan yaitu kualitas pelayanan, kualitas produk, dan harga, sedangkan 2 faktor lainnya diluar kendali pemasar yaitu faktor situasional dan faktor personal.

Menurut Putri dan Sunaryanto (2020), pengaruh produk, harga, kualitas pelayanan, promosi dan lokasi terhadap keputusan konsumen, secara parsial mempunyai pengaruh signifikan terhadap kepuasan pelanggan, dan secara simultan atau bersama-sama mempunyai pengaruh signifikan terhadap kepuasan pelanggan. Melihat masingmasing variabel memiliki pengaruh yang signifikan maka disarankan kepada pelaku usaha atau IKM Batik Benang 


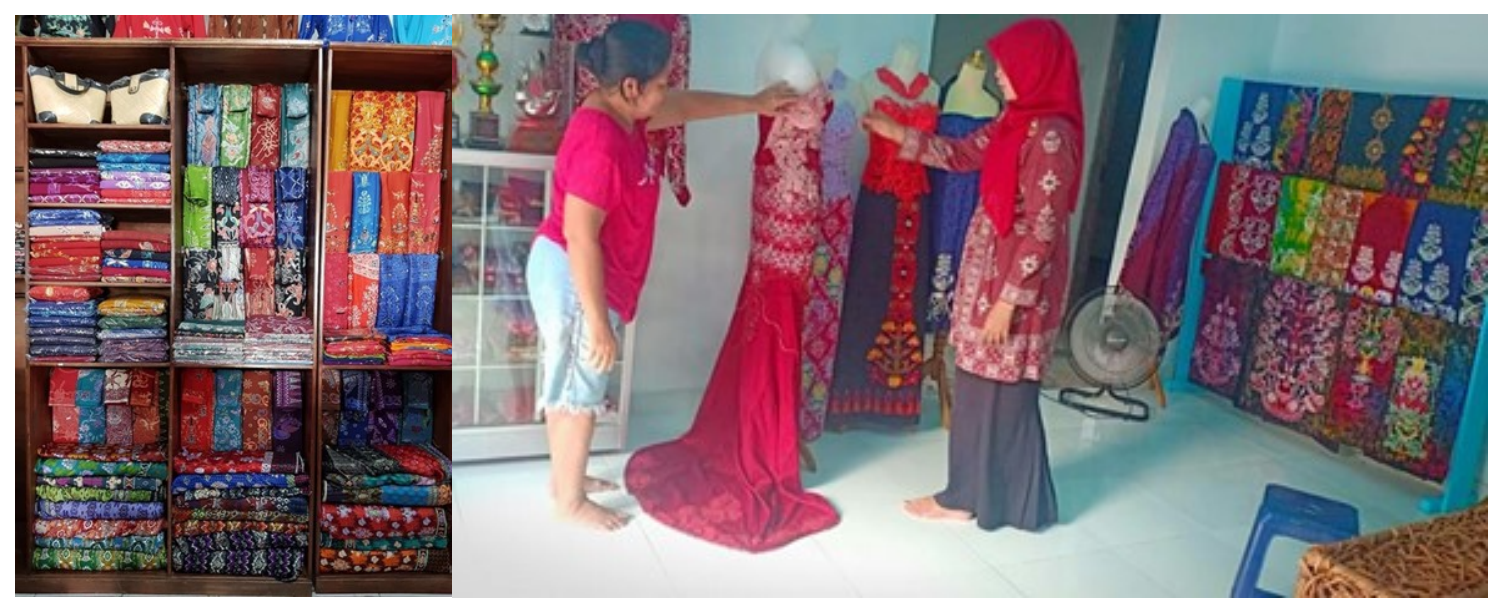

Gambar 1. Ragam motif Batik Benang Bintik khas Kalimantan Tengah

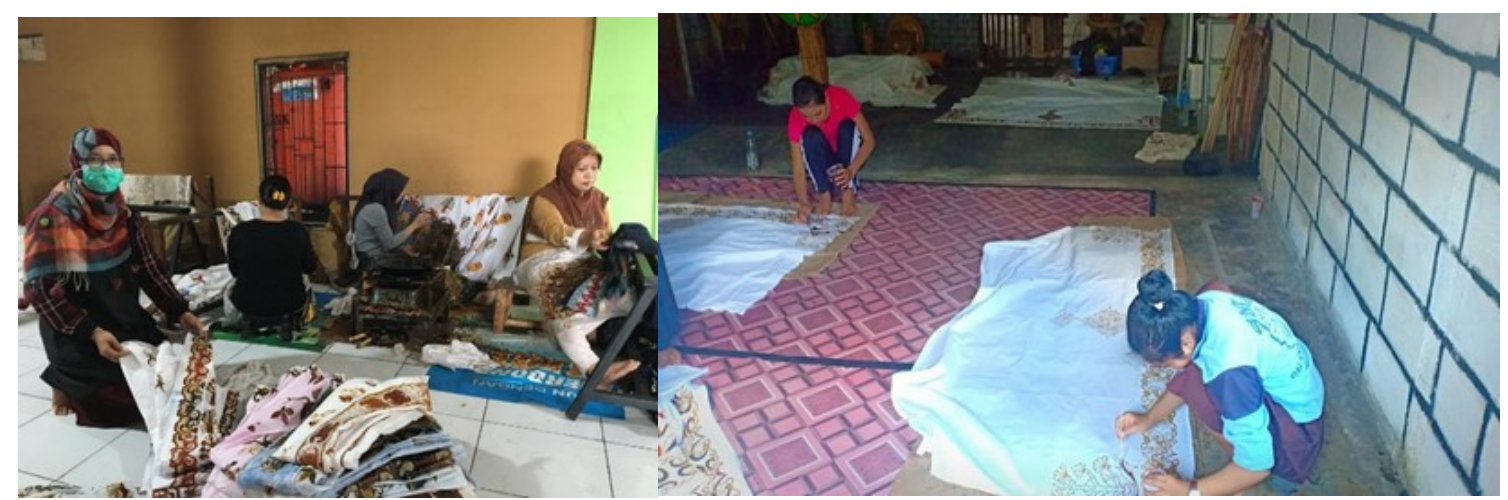

Gambar 2. Proses Produksi Batik Benang Bintik

Bintik di Kota Palangka Raya untuk meningkatkan pelayanan, promosi, harga dan lokasi untuk dapat meningkatkan kepuasan yang lebih tinggi kepada pelanggan di masa yang akan datang. Selain itu, perlu diciptakannya strategi lain dalam meningkatkan persaingan dalam usaha bisnis, seperti aspek meningkatkan citra dan reputasi pelaku usaha atau IKM Batik Benang Bintik di Kota Palangka Raya melalui iklan, serta menciptakan brand image pada setiap produk yang ditampilkan.

Peningkatan kepuasan terhadap Batik Benang Bintik juga juga dapat dipengarhi oleh faktor-faktor psikologis, misalnya dengan mengetahui filosofi-filosofi dibalik motif batik Dayak. Beberapa motif khas kebudayaan suku Dayak antara lain seperti alat tradisional, rumah adat, pohon Batang Garing dan lukisan-lukisan khas suku Dayak Ngaju (Gambar 1). Terdapat banyak makna yang tersirat dalam setiap motif batik Benang Bintik seperti halnya motif pohon Batang Garing yang memiliki makna sebuah ikatan yang kuat antara manusia, langit, bumi dengan keberadaan Raying Hatalla (Tuhan dalam keyakinan Hindu Kaharingan) serta motif Balanga dan Ukir Tingang Ranggaban Patung Nyahu melambangkan kesucian. Selain itu, yang menjadi ciri khas Batik Benang Bintik terletak pada motif warna yang digunakan dimana warna yang digunakan pada awal munculnya batik Benang Bintik Kalimantan Tengah adalah
Bahenda (kuning) berasal dari warna kuning yang bermakna keagungan dan kekayaan (Kalteng.net, 2014). Selain itu pelanggan juga dapat disuguhi informasi tentang proses pembuatan Batik Benang Bintik yang dilakukan secara tradisional (Gambar 2). Pemahaman nilai-nilai kultural lokal dapat memingkatkan kepuasan pelanggan pada saat mengenakan batik tersebut.

\section{KESIMPULAN}

Berdasarkan Hasil penelitian didapatkan bahwa secara keseluruhan tingkat kepuasan pelanggan adalah sebesar $82,8 \%$ terhadap batik benang Bintik di Kota Palangka Raya jika ditinjau dari 4 (empat) aspek yakni pelayanan, promosi, harga, dan lokasi. Berdasarkan data tersebut, tentu angka tersebut tergolong cukup tinggi jika dibandingkan dengan besarnya persentasi pelanggan yang menganggap biasabiasa saja atau bersikap netral yaitu hanya sebesar $15,3 \%$. Sedangkan ketidakpuasan pelanggan sebesar 1,9\% terhadap Batik Benang Bintik di Kota Palangka Raya dimana ketidakpuasan tersebut terdapat pada aspek promosi dan lokasi. 


\section{DAFTAR PUSTAKA}

Adriani, V., dan Realize. 2018. Pengaruh Kualitas Pelayanan dan Promosi Terhadap Kepuasan Pelanggan Pengaruh Kualitas Pelayanan dan Promosi Terhadap Kepuasan Pelanggan Pada PT. Stainlessindo Anugrah Karya Di Kota Batam. Jurnal Pundi, 2(2), 169-180. https:// doi.org/10.31575/jp.v2i2.78

Alexandro, R., Putri, W.U. and Nurmawati, Y., 2020. Analisis Swot pada Pemasaran Batik Benang Bintik Lestari Indah Palangka Raya. Ekuitas: Jurnal Pendidikan Ekonomi, 8(1), 71-79.

Arikunto, S., 2006. Prosedur Penelitian Suatu Pendekatan Praktik. Jakarta: Rineka Cipta.

Kalteng.net. 2014. Benang Bintik, Batik Khas Kalimantan Tengah (diolah dari berbagai sumber oleh Wawan Wiraatmaja). Tersedia online di: http://kalteng.net/? $p=102$. [2 October 2014].

Kementerian Perindustrian Republik Indonesia. 2018. Analisis Perkembangan Industri, Indonesia.

Kertajaya, H. (2002). MarkPlus on Strategy: 12 Tahun Perjalanan. Jakarta: Gramedia

Kotler, P., dan Armstrong, G. 2017. Prinsip-prinsip Pemasaran. Edisi 12. Jakarta: Erlangga.

Kurniasih, R., 2018. Analisis perilaku konsumen terhadap produk batik tulias Banyumas. Jurnal Ekonomi, Bisnis, dan Akuntansi, 20(1), 1-12.

Kustiyah, I.E., 2017. Batik sebagai identitas kultural bangsa Indonesia di era globalisasi. Gema, 30(52), p.62476.

Mang, J., Zainal, R. and Radzuan, I.S.M., 2018. Influence of Location Attributes on Home Buyers 'Purchase Decision. International Journal of Supply Chain Management, 7(3), 94-100.

Nurainun, N., 2008. Analisis industri batik di Indonesia. Fokus Ekonomi, 7(3), p.24399.

Parasuraman, A., Zeithaml, V.A. and Malhotra, A., 2005. ESQUAL: A multiple-item scale for assessing electronic service quality. Journal of service research, 7(3), 213-233.
Purba, S.L. and Prasetyo, P.E., 2018. Analisis Faktor Produksi Terhadap Daya Saing Batik Semarangan. Economics Development Analysis Journal, 7(3), 260-267.

Putri, D. C., \& Sunaryanto, L. T., 2020. Pengaruh Produk, Harga, Kualitas Pelayanan, Promosi Dan Lokasi Terhadap Keputusan Konsumen Berkunjung Di Kampoeng Banyumili Semarang Jawa Tengah. Jurnal Ilmiah Mahasiswa Agroinfo Galuh, 7(3), 579-590.

Rahayu, E., 2018. Pengaruh Lokasi, Kelengkapan Produk, dan Pelayanan terhadap Keputusan Pembelian Konsumen pada Imam Market Kisaran. Journal of Science and Social Research, 1(1), 7-12.

Stanton, W. J., 1998. Prinsip Pemasaran Edisi Ketujuh Jilid 1. Jakarta: Erlangga.

Sugiyono. 2017. Metode Penelitian Kuantitatif, Kualitatif, dan $R \& D$. Bandung: Alfabeta.

Suwartono, C. and Moningka, C., 2017. Pengujian validitas dan reliabilitas skala identitas sosial. Humanitas: Jurnal Psikologi Indonesia, 14(2), 176-188.

Tjiptono, F., 1999. Stretegi Pemasaran. Edisi kedua. Yogyakarta: Indeks.

Unaradjan, D. D., 2019. Metode penelitian kuantitatif. Penerbit Unika Atma Jaya Jakarta.

Wibowo, E., Rokhmat, M., Rahman, D.Y., Murniati, R. and Abdullah, M., 2017. Batik Wastewater treatment using TiO2 nanoparticles coated on the surface of plastic sheet. Procedia engineering, 170, 78-83.

Wahyuni, P.R. and Kurniawan, D.T., 2019. Pengaruh Interaksi Harga dan Desain Atau Motif Batik Terhadap Keputusan Pembelian Batik. Cemara, 16(1), 8-16.

Widiasti, D., Hamidi, W. and Jahrizal, J., 2017. Pengembangan Industri Batik Riau pada Rumah Kreatif Cempaka di Kecamatan Rumbai Pesisir Kota Pekanbaru. JOM Fekon, 4(1), 475-489.

Yusup, F., 2018. Uji validitas dan reliabilitas instrumen penelitian kuantitatif. Tarbiyah: Jurnal Ilmiah Kependidikan, 7(1), 17-23. 